\title{
Statistical Analysis and Evaluation of Changing Trend of Woman Employment in Turkey in Globalization Conditions
}

\author{
Assoc. Prof. Dr. Necati KAYHAN \\ Head of Labour Inspectour
}

\begin{abstract}
Women in the status of a milestone in a family, who can also become the mother, are given more responsibility compared to man. In this sense, working woman has some very crucial responsibilities both individually and socially and economically. Besides these roles, the involvement of women comprising almost half of the population in working life actively and contribute to production is of importance in the development of country and fight against poverty. Therefore, in the current time, a great many incentives have been given in socioeconomic sense recently in order to increase the woman employment in Turkey, which is much behind OECD data, to the desired level. However, even though the activity in woman employment has partly improved quantitatively in recent years despite these measures, necessary improvement in providing them a proper job qualitatively have not been obtained. Some reasons for this could be summed as follows: gender discrimination, inadequate growth, scarcity in proper job, lack of innovative and entrepreneurial education model for labour market, rapid urbanization, qualitative labour force, job experience etc. Women could only find an opportunity for a job in atypical working forms such as easiest one, without a union, without protection, demanding a cheap labour force with sub-employers. In this sense, in the current study that was carried out to describe women employment in Turkey, it was aimed to investigate involvement in labour force, working types and conditions. The method to be used in the study was planned as determining and evaluating the condition in the working life of women and changing trend in the country with a basis of examining current national and international studies and statistical data with regard to woman employment in the last five years.
\end{abstract}

Keywords: Woman Labour Fore, Unemployment, Employment Trend, Reasons and Solutions

\section{1-Introduction}

Active involvement of women comprising almost half of the population of the country into working life is of great importance in the development of a country and in the struggle with poverty. However, despite all efforts, the rate of the women involvement in the workforce in Turkey as a developing country is around 34\%. According to latest 2017 OECD report, women in Turkey take its place much below the average of OECD countries in terms of the level at the rates of both workforce and involvement in employment (OECD.Employment-Outlook-Turkey-2017.pdf). In this sense, depending on such international foundation reports as OECD and ILO, the status of the women employment in Turkey shows that it is at the low levels in terms of such qualitative tasks as being able to get equal job and carried in the parliament and public service, being an employer, secured job, gender equality, having the right of being a member of a union, job befitting to a socially secured person as the universal criteria having a significance for the equal presentation they have and working rights in the country. As shown in Table 1, even though there is a partly improvement in the involvement of women in employment quantitatively according to similar criteria because of increasing incentives and social policies in Turkey in recent years, the same improvement cannot be observed in quality. Unfortunately, there are some lacking quality such as gender discrimination, wage level, proper job, obtaining qualitative working conditions in the sense of job and home balance. Information about 2017 OECD-Outlook Report showing the quality level of Turkey in women employment is given in Table 1. 


\section{Table 1. Performance Level of Employment in Turkey}

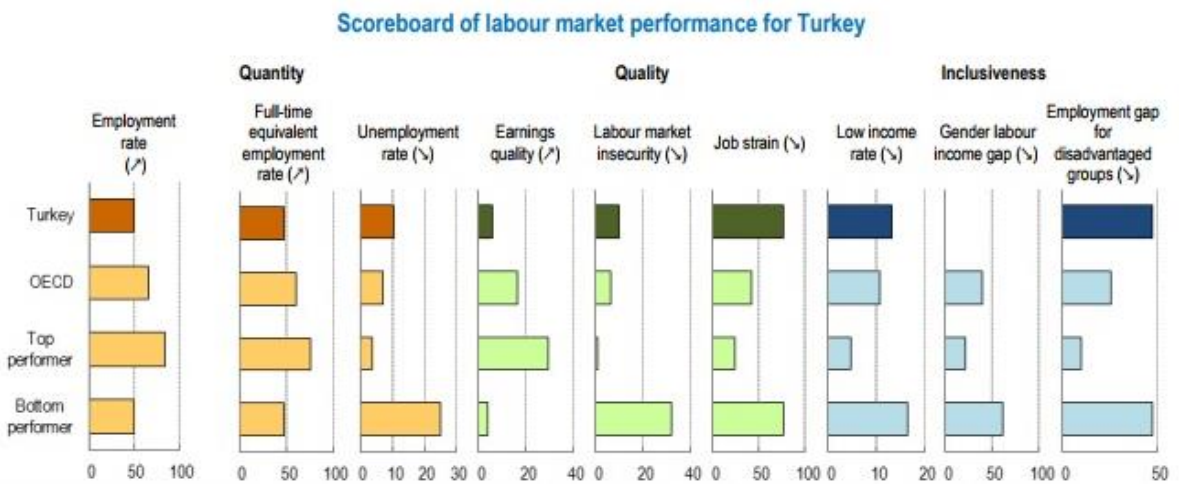

Note: An upward $\lambda$ (downward $\searrow$ ) pointing arrow for an indicator means that higher (lower) values reflect better performance.

Earnings quality: Gross hourly earnings in USD adjusted for inequality. Lobour market insecurity: Expected monetary loss associated with the risk of becoming unemployed as a share of previous earnings. Job strain: Percentage of workers in jobs characterised by a combination of high job demands and few job resources to meet those demands. Low income rate: Share of working-age persons living with less than $50 \%$ of median equivalised household disposable income. Gender labour income gap: Difference between average per capita annual earnings of men and women divided by average per capita earnings of men. Employment gap for disadvantoged groups: Average difference in the employment rate for prime-age men and the rates for five disadvantaged groups (mothers with children, youth who are not in full-time education or training, workers aged 55-64, non-natives, and persons with disabilities) as a percentage of the employment rate for prime-age men.

Source and definitions: OECD calculations using data for 2015 or latest year available from multiple sources. See OECD Employment Outiook 2017

Women in Turkey are mostly intensified in atypical working fields with low wage, flexible, with no insurance and long and strong working conditions developing as a result of neoliberal policies caused by globalization (Karadeniz-2011). As seen in the table below, agriculture sector as a working field, small businesses, textile sector and basic work needing no qualification and health, elderly and childcare services which cannot be easily recorded could be given as examples. The sectors with rare women workforce could be given as high level management, public service, jurisdiction, industrial affairs and business and trade affairs.

Table 2. Common Women Occupations in Turkey (2012, Thousand person, 15+ age)

Total

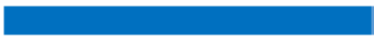

7.309

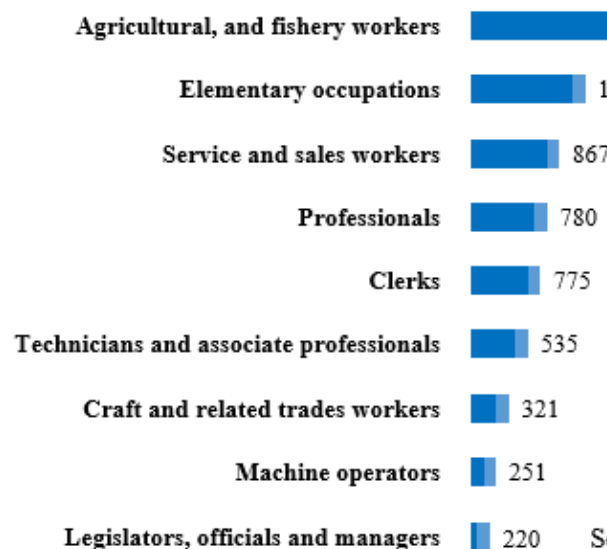

2.101

1.459

Source : Hürriyet Daily News-November-2015 
Because of the reasons mentioned, the country with highest score according to the 2016 Global Gender Gap of World Economic Forum is Island while Turkey had its place at 130th rank among 144 countries (http://www.dw.com/tr/türkiyenincinsiyet--karnesi/). The most important indicator of women employment quality is the rank of gender discrimination. As given Table 3 which was arranged according to the geographical features of countries in this issue, Southern Asian countries where Turkey is included are not in a good position in Gender Discrimination in terms of Workforce Involvement and it shows that Turkey has a performance close to Western African and Middle East countries (ILO,2017).

Table 3. Labour force participation rate by sex (per cent) and gender gap (percentage points), 1997-2021

\begin{tabular}{|c|c|c|c|c|c|c|c|c|}
\hline \multirow[t]{2}{*}{ Country/region } & \multirow{2}{*}{$\begin{array}{c}1997-2017 \\
\text { Gap }\end{array}$} & \multicolumn{3}{|c|}{2017} & \multicolumn{3}{|c|}{2018} & \multirow{2}{*}{$\frac{2018-21}{\text { Gap }}$} \\
\hline & & $\delta$ & ㅇ & Gap & $\delta$ & ㅇ & Gap & \\
\hline World & & 76.1 & 49.4 & 26.7 & 76.0 & 49.3 & 26.7 & $\Rightarrow$ \\
\hline Developing countries & & 82.6 & 70.3 & 12.3 & 82.6 & 70.3 & 12.3 & $\Rightarrow$ \\
\hline Emerging countries & & 77.5 & 46.9 & 30.6 & 77.4 & 46.7 & 30.7 & $\boldsymbol{1}$ \\
\hline Developed countrles & & 68.0 & 51.9 & 16.1 & 67.9 & 51.8 & 16.1 & + \\
\hline Northern Africa & & 74.1 & 22.9 & 51.2 & 74.1 & 22.9 & 51.2 & 4 \\
\hline Sub-Saharan Africa & & 76.3 & 64.6 & 11.7 & 76.4 & 64.7 & 11.7 & $\Rightarrow$ \\
\hline Latin America and the Caribbean & & 78.3 & 52.7 & 25.6 & 78.3 & 52.7 & 25.6 & 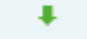 \\
\hline Northern America & & 68.3 & 56.2 & 12.1 & 68.1 & 58.1 & 12.0 & $\Rightarrow$ \\
\hline Arab States & & 76.4 & 21.2 & 55.2 & 76.3 & 21.3 & 55.0 & + \\
\hline Eastern Asia & & 76.8 & 61.3 & 15.5 & 76.6 & 60.9 & 15.7 & $\mathbf{1}$ \\
\hline South-Eastern Asia and the Pacific & & 81.2 & 58.8 & 22.4 & 81.1 & 58.8 & 22.3 & $\Rightarrow$ \\
\hline Southern Asia & & 78.4 & 28.6 & 50.8 & 78.5 & 28.7 & 50.8 & $\forall$ \\
\hline Northern, Southern and Western Europe & & 63.8 & 51.3 & 12.5 & 63.6 & 51.2 & 12.4 & + \\
\hline Eastern Europe & & 68.1 & 53.0 & 15.1 & 67.8 & 52.9 & 15.0 & 4 \\
\hline Central and Western Asia & & 73.5 & 44.1 & 28.4 & 73.5 & 44.1 & 28.4 & $\Rightarrow$ \\
\hline
\end{tabular}

Notes: Throughout this report, figures for 2017 and beyond are projections. Developments for the period $2018-21$ are marked with a red upward arow if the jap is projected to widen by more than 0.1 percentage points, by a green downward arrow if it is projected to namrow by move than 0.1 percentage points, and a biack hanizontal arrow for developments in between. Numbers in the "Gap" columns refer to the percentage point difference between the male and female labour force partlcipation rates or the change over time but may not correspond precisely due to rounding.

Source: ILO'S Trends Econometric Models, November 2016.

Even though women employment has partly improved quantitatively, necessary improvement has not been obtained qualitatively. In order to increase women employment in Turkey to the desired level, a great many incentives have been given recently, particularly socio-economic ones. As a result of the studies mentioned, an improvement has been obtained in the economy but there hasn't been a decrease in unemployment at the desired level. However, a partly increase has been obtained in women employment, nevertheless, similar improvement has not been obtained in getting a qualitative occupation (Source: TÜRKONFED 1. Faz Rapor-2017, Yıldız-2013). According to TSI (Turkish Statistics Institution) July2017 data, non-agriculture men unemployment in Turkey was 12.4\% while non-agriculture women unemployment was around $17.7 \%$. In this sense, the primary problem of Turkey, as the outcomes of questionnaires reveal, seems to be unemployment and woman poverty after terror problem. For that reason, the state was regarded as responsible for guaranteeing the right to work as a social state principle, which is one of the basic principles of the constitution (1982, Const., Art. No 10,50) (Ülger, 2017:24). As a matter of fact, this issue was mentioned in such international texts as Human Rights Declaration, CEDAW, European Social Charter, and ILO and the state was regarded as responsible primarily for the solution of the problem (http://www.tbmm.gov.tr). However, in the current issue, despite the efforts made, the problem of women unemployment is still rising in Turkey keeping its importance (Table ILO -2017).

In order to fight against woman problem actively in the current process, it is necessary to deal with such problems as education, woman and man discrimination, job and family life balance and lack of proper job. The most intensive part of the atypical working forms employing cheap workforce that is caused by globalization conditions, neoliberalism and excessive competition environment is made up of women and young people as the disadvantageous part of the population in Turkey as in the world (Tire, 2017). 
For that reason, women unemployment is one of the problems with a priority in Turkey. The employment status and quality of the workforce countries have is one of the basic indicators of the economic developments in these countries. It is necessary that countries must include the workforce they have into production in an active way for development, as workforce is the most valuable and strategic one of the production factors just like the head in the human body. However, the women who are expected to become the motor power of the country in the development of the country in current conditions regarding the reasons mentioned could remain in an idle position because of lack of necessary opportunities. This study provides insights into women employment problematic in Turkey. Accordingly, the study begins with the definition and the measurement way of women employment and unemployment. Causes of women unemployment and the recent global labour market trends concerning women are examined. The structure of women employment and the characteristics of women unemployment in Turkey are discussed. The study is completed with the conclusive remarks comprising suggestions to policy makers concerning the issue.

\section{2-Methods}

Major data in this study have been obtained from International Labour Office-Key Indicators of Labour Market (KILM), Turkish Statistical Institute (TUIK) and Organization for Economic Corporation and Development (OECD). Moreover, the related literatures have been used. Statistical methods such as means and percentages have been used in the study.

\section{3-Findings and Discussion}

Just as the fact that a person can use his right arm in his life but cannot use the left arm effectively is of importance, it is also important that women has a proper job and involve in employment for both a community and woman individuals. As a matter of fact, the similar finding in the report by International Labour Organization (ILO) in 2017 with regard to the importance of this problem called "Global Trends in Women Employment" are quite striking. According to ILO, with the elimination of other handicaps peculiar to country by decreasing gender discrimination particularly, both women and community and economy will gain very significant benefits. It is also estimated in the up-to-date report of ILO that if current difference between women and men could be decreased in terms of the rates of global involvement in workforce as $25 \%$, the reflection of it to the global economy would be 5.8 trillion dollars (ilo.2017.world.pdf). For that reason, as many international expert institutions mentioned, Turkey, paying the token of women employment problem heavily, is at the $130^{\text {th }}$ rank among 145 countries in the field of Turkey Economic Involvement and Opportunities according to the report of "Global Gender Inequality" of World Economic Forum (WEF) 2015 and it is indicated that Turkey does not deserve such a rank and it is expected to improve its place. In order to realize it, it is necessary that the education level of women in Turkey, which is of importance in catching the real involvement in the social and economic life (key role in involvement in employment) as well the success, must be increased depending on the work marked and the occupations in the future; as Turkey is still at a bad performance level of $105^{\text {th }}$ rank in woman education according to WEF 2015 report. In this sense, it is of great importance to solve the problems women employment such as income distribution, poverty, and social welfare. It is of vital importance to deal with some basic indicators with regard to the women employment in Turkey in order to clarify the dimensions of the problem.

As for the profile of women employment in general employment in Turkey, it is likely to say that according to TSI 2016-2017 data, 40 million of the population is made up of men and 39 million is comprised of women in Turkey, which is regarded as a developing country as shown in the table. In the period of 2016, while men employment rate of $14-65$ age group is $78 \%$, the rate of women employment is $38 \%$, the rate of involvement in workforce in men is $71 \%$ and $32 \%$ in women. The rate of women neither in education nor in employment is $34 \%$ while it is $13.8 \%$ in men. The rate of non-agriculture unemployment in women is $19 \%$, it is $9.9 \%$ in men (Table, 4 ).

Table 4: Seasonally Unadjusted Basic Workforce Indications. June 2016 - June 2017.

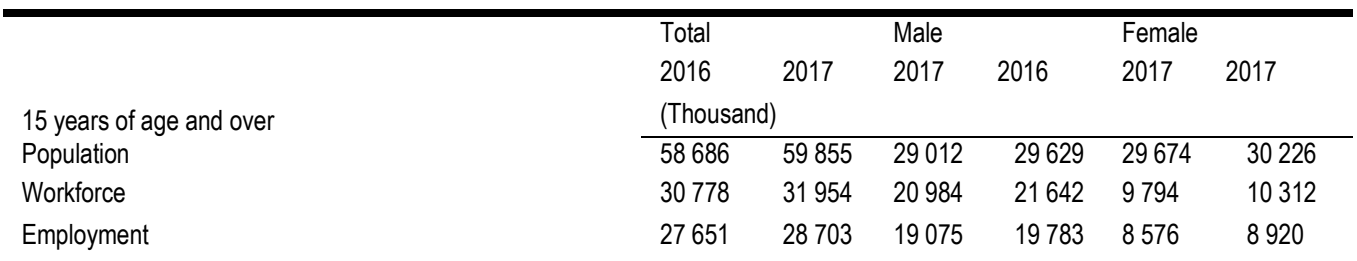


Agriculture

Non-agriculture

Unemployed

Those not included in the workforce

Rate of involvement in workforce

Rate of employment

Rate of non-agriculture unemployment

15-64 age group

Rate of involvement in workforce

Rate of employment

Rate of unemployment

Rate of non-agriculture unemployment

Young Population (15-24 age)

Unemployment rate

Rate of those neither in education nor at employment (1)

\begin{tabular}{|c|c|c|c|c|c|}
\hline 5577 & 5757 & 3003 & 3079 & 2574 & 2678 \\
\hline 22074 & 22946 & 16072 & 16704 & 6001 & 6242 \\
\hline 3127 & 3251 & 1909 & 1858 & 1218 & 1393 \\
\hline 27908 & 27901 & 8028 & 7987 & 19881 & 19914 \\
\hline 52,4 & 53,4 & 72,3 & 73,0 & 33,0 & 34,1 \\
\hline 47,1 & 48,0 & 65,7 & 66,8 & 28,9 & 29,5 \\
\hline 10,2 & 10,2 & 9,1 & 8,6 & 12,4 & 13,5 \\
\hline 12,2 & 12,2 & 10,4 & 9,9 & 16,7 & 18,0 \\
\hline 57,5 & 58,6 & 78,0 & 78,8 & 36,8 & 38,2 \\
\hline 51,5 & 52,5 & 70,8 & 78,8 & 36,8 & 38,2 \\
\hline 10,4 & 10,4 & 9,3 & 8,8 & 12,7 & 13,8 \\
\hline 12,3 & 12,3 & 10,5 & 9,9 & 16,8 & 18,1 \\
\hline 19,4 & 20,6 & 17,4 & 17,2 & 22,9 & 26,8 \\
\hline 23,8 & 24,0 & 14,7 & 13,8 & 33,0 & 34,5 \\
\hline
\end{tabular}

The number might not give the overall total as they were not rounded up.

(1) The rate of youth nonworking and not included in education (formal and widespread) in total youth population.

Source : TSI-2016-2017

Another indicator regarding the quality of woman employment is the sense of gender discrimination encountered in employment.

When it comes to the types of women employment, the involvement of women in employment, mostly in the service sector, increased year by year, as given in Table 5 . However, women workers with their peculiar status only work near to men only in the agriculture sector.

\section{Table 5: Sectors Working According to Gender in Turkey}

\begin{tabular}{|l|l|l|l|l|l|l|l|l|}
\hline 15 years of age and over & 2014 & & 2015 & & 2016 & 2017 (June) \\
\hline & Men & Women & Men & Women & Men & Women & Men & Women \\
\hline $\begin{array}{l}\text { Sectoral Distribution of } \\
\text { Employment }\end{array}$ & 18.244 & 7.689 & 18.562 & 8.058 & 18.893 & 8.312 & 19.784 & 8.933 \\
\hline Agriculture & 2.937 & 2.533 & 2.956 & 2.527 & 2.920 & 2.384 & 3.079 & 2.678 \\
\hline Industry & 4.080 & 1.236 & 4.101 & 1.231 & 4.058 & 1.239 & 4.098 & 1.285 \\
\hline Construction & 1.832 & 79 & 1.843 & 70 & 1.904 & 83 & 2.094 & 91 \\
\hline Service & 9.395 & 3.841 & 9.662 & 4.230 & 10.011 & 4.606 & 10.513 & 4.879 \\
\hline
\end{tabular}

Source: TSI 2017- HHIA

Another factor showing the quality in women employment in countries is that one can work in the public service which is mostly preferred as it has insurance. As shown in Table 6, men are overwhelmingly on the forefront in terms of public service employment.

\section{Table 6: Distribution of Public Workers Regarding Gender}

\begin{tabular}{|l|l|l|}
\hline Gender & Total Worker & Rate of Workers (\%) \\
\hline Women & 1.171 .816 & 37.80 \\
\hline Men & 1.928 .153 & 62.20 \\
\hline Total & 3.099 .969 & 100.00 \\
\hline
\end{tabular}

Source: State Personnel Department Presidency Statistics-2013

As of occupational branches worked, men are in the forefront at such occupations as high level manager with a rate of $90.7 \%$, professor as $71.8 \%$, judge as $63.7 \%$ and policeman as $94.5 \%$ compared to women. It is known that women come 
near to men only in such elite professions as professor with a rate of $28.2 \%$, judge with a rate of $36.3 \%$ (TSI, Women through Statistics; 2013).

While the majority of women employment in Turkey is comprised of waged works as $65 \%$, family workers working free of charge are in the second place with a rate of $28.4 \%$. The rate of women working as employers is only $10 \%$. It shows that this rate of being an employer is behind that of EU level, which is $27 \%$. Statistics show that $46.1 \%$ work out of record. The rate for men is $28 \%$ (TSI-2015). According to all these key indicators regarding Turkey, women are behind men in labour life.

Even though it matches up with the developing countries in the world, there are some problems putting preventing women employment peculiar to Turkey. Up-to-date table of ILO showing the components preventing women employment allowing to make a universal comparison between global problems and those of Turkey give the details (Table 7).

Table 7: The Weight of Elements Preventing Women Employment According to Geographic Regions

\begin{tabular}{|c|c|c|c|c|c|c|c|}
\hline & \multirow{2}{*}{$\begin{array}{l}\text { Prefer } \\
\text { to work }\end{array}$} & \multicolumn{6}{|c|}{ Challenges reported in the labour market } \\
\hline & & $\begin{array}{l}\text { Work and } \\
\text { family } \\
\text { balance }\end{array}$ & $\begin{array}{l}\text { Lack of } \\
\text { affordable } \\
\text { care }\end{array}$ & $\begin{array}{c}\text { Family } \\
\text { members } \\
\text { don't approve }\end{array}$ & $\begin{array}{c}\text { Abuse/ } \\
\text { harassment/ } \\
\text { discrimination }\end{array}$ & $\begin{array}{l}\text { Lack of } \\
\text { good-paying } \\
\text { jobs }\end{array}$ & $\begin{array}{c}\text { Unequal } \\
\text { pay }\end{array}$ \\
\hline Worid & 79.2 & 24.6 & 9.6 & 4.3 & 10.3 & 9.5 & 6.5 \\
\hline Northern Africa & 69.9 & 30.5 & 6.5 & 9.6 & 245 & 7.9 & 3.1 \\
\hline Sub-Saharan Africa & 85.4 & 19.2 & 11.9 & 9.8 & 14.9 & 7.9 & 3.4 \\
\hline Latin America and the Carlobean & 74.9 & 22.5 & 14.2 & 3.6 & 9.6 & 7.7 & 6.1 \\
\hline Northern America & 79.1 & 23.0 & 7.5 & 0.8 & 10.0 & 2.6 & 31.8 \\
\hline Arab States & 70.5 & 29.4 & 4.5 & 7.5 & 9.8 & 9.1 & 3.8 \\
\hline Eastern Asla & 79.8 & 21.7 & 22.4 & 1.2 & 6.7 & 7.4 & 3.6 \\
\hline South-Eastern Asla and the Paciflc & 81.2 & 26.6 & 7.3 & 1.2 & 8.8 & 6.6 & 5.8 \\
\hline Southern Asla & 50.1 & 20.0 & 8.3 & 11.3 & 11.3 & 4.5 & 2.3 \\
\hline Northern, Southern and Western Europe & 84.8 & 33.9 & 5.1 & 1.4 & 8.0 & 6.5 & 14.0 \\
\hline Eastern Europe & 75.4 & 25.0 & 4.4 & 0.7 & 6.1 & 23.8 & 7.0 \\
\hline Central and Western Asla & 79.8 & 23.2 & 8.7 & 8.6 & 6.9 & 16.7 & 3.5 \\
\hline
\end{tabular}

Notes: This table sccounts for the survey sample of a total of 70,561 observations representing the survey responses of women in 127 countries. Population weights are appliled accordingly to achleve equal country representation. Resuits may vary silghtly to those pubilished in Galiup-ILO, 2017 due to country soverage. Darker shading indicates the top two challenges in the region. See Appendix $C$ on weighting methods.

Source: Gallup-ILO-2017

There are many reasons triggering poverty, pulling women into a disadvantageous inertia position making it different from developed countries. Some of them are; difficulty in having an access to qualitative job and education, roles of childcare and elderly care, scarcity of qualitative job in labour market, unattractiveness of unqualified jobs with low wages, preserving home and work balance. Besides that, the biggest handicap in the evaluation of woman workforce potential in Turkey well enough results from the fact that the prejudice of baseless gender discrimination in the community cannot be broken, which is not related to Turkish-Islam culture encouraging women as every other individuals to be beneficial for humanity (as a producer) with such golden key discourses as "The best of people are those who are most beneficial to other people", "Learning science is obligatory upon both man and woman", "The giving hand is better than taking hand", "If two days of a person are equal, he is in loss", "Paradise is beneath the feet of mothers" with an idea of training qualitative people (Acar,2015). The main problem results from illiteracy and from the prejudiced perspective for women who are the main stones of a healthy community. For that reason, there is a serious need for following up a positive discriminative attitude toward our daughters and women who have to start a disadvantageous life in unconscious societies by having such a prejudiced attitude. In the sense of standing still on her own and having a tie with life, providing adequate education and proper job opportunities required by the positive discrimination principle written in the constitution of a social state in order to improve the skills of poor and needy women in disadvantageous position particularly in developing countries like Turkey is of great importance. 


\section{Conclusion and Recommendations}

Training women having the most strategical significance in the development of communities and preparing the people for the future would only be possible through making them have a fully equipped job in all sense. Otherwise, becoming free from the position of a weak country accepting aids and orders is hard as it is not possible to run with only one leg. In general, the problem of woman employment which is peculiar to underdeveloped or developing countries has some many dimensions such as gender discrimination, lack of proper and humanely job, work and family balance problems. However, as a solution, it is necessary at first hand to believe the importance of the involvement of women, the milestones of a community, in employment principally. In addition, it is expected that the state as the as the main role player must be leading in solving all problems comprising a handicap for women employment as a principle of a social state in the constitution through international treaties (UN CEDAW, ILO) to support the development of a society (Turkish Constitution, Articles 10, 41, 49, 50); as solving the problem of women employment leading to chaos in the globalization conditions bringing about an excessive comparison peculiar to our age do not look so easy. For these reasons, it is necessary provide qualitative vocational education to allow women to improve their talents, a nursery school where they will not have any familial problems, social service aids like care and bus service etc., a proper job, secured but flexible working conditions and opportunities in order to solve such preliminary problems preventing women employment. As a conclusion, it is known to us that women who are in a disadvantageous position in many ways compared to men in a society are prone to any kind of exploitation mainly to labour in the materialist, excessive competition working environment as a product of a capitalist system. As a solution, it is necessary to support women through social policies to be followed by all official and voluntary institutions in a society in order to prevent such kind of destructive problems.

It is necessary for a healthy result to get the balance of production-consumption and wage trio in economies in the first hand in order to prevent women unemployment and poverty. For that reason, making all the activities to be carried out both at micro and macro levels aiming at competing against the women unemployment to have a focal point of teaching people how to catch fish instead of giving them fish and of a good employment should be evaluated as the most important task out of the ones envisaged as the principle of a social state. Because of all these reasons, making the young adapt to society means making them employed first.

It is likely to say in this context that the eventual exit is to give them equal opportunity in work life, politics, economy, in all stages of life to take active responsibility and provide them with the chance to involve in the decision making positions at every stage.

\section{Sources}

[1] ACAR Y.(2015). " Kardeşlik Ahlakı ve Sorumluluğu , TDVY. Ankara,p.290

[2] AKGEYIK ,T.,(2000). "Teknolojik Değişim Post - Fordist Eğilimler ve Endüstri llişkilerinde Yeni Arayışlar”, Journal of Çimento Işveren, Volume 14, Issue No 3, Ankara

[3] ASLAN, E.,(2016). "İ̧sgücü Piyasası Araştırmaları Kapsamında, Aktif İ̧gücü Hizmetleri Değerlendirmesi" İ̧KUR, Journal of İstihdam, Issue No,18, Ankara, January-2016, p.40

[4] BAKIRCI K. (2012). "Cinsiyet Ayrımclığı Yasağı ve Türkiye" Seçkin,cAnkara

[5] BOYACIOĞLU, E. ( 2011)" Dünyada ve Türkiye de Kadııın Işgücüne Katıımının Projeksiyonu Ed. "Moroğlu N., Woman and Poverty, CM Publications, ìstanbul

[6] BALKIR Z. Vd. (2011). "Küreselleşmenin Kadının Yoksulluğu na Etkisi" ed. Moroğlu N.Woman and Powerty, CM Publications, İstanbul

[7] ÇSGB-ISKUR 2016-2018 Action Plan for Women Employment, file:/l

[8] /C:/User/AppData/Local/Microsoft/Windows/INetCache/IE/VYBO3MWJ/wcms_484715.pdf

[9] DERTLi, N.,(2007) "Aktif İstihdam Politikaları, Eleştirel Bir Yaklaşım", Ankara University, Institute of Social Sciences Unpublished Master Thesis, Ankara, 2007.

[10] DOĞANALP B.-Afşar B. ( 2014) Kadın Girişimcilerin Profil Analizi : Ed. Afşar Doğanalp, Kadın Girişimciliğ, Sample of City of Konya,

[11] ERDAYI, A. U., (2016). "Dünya da Genç İşsizliği, Sorunu Çözümüne Yönelik Ulusal Politikalar ve Türkiye" Journal of Çalışma ve Toplum Hukuk Issue No, 22, Access: http://calismatoplum.org/22/Erdayi.pdf.p.112,

[12] EUROSTAT,(2015). "Growth incidence of temporary employment among women, European countries, 2007-14", Database of the European Union Labour Force Survey.

[13] EUROSTAT (2017)http://ec.europa.eu/eurostat/statistics-explained/index.php/Gender_statistics\#tLabour_market

[14] FREEMAN, R. (1979). Why Is There A Youth Labour Market Problem, NBER Working Paper No.365, National Bureau of Economic Research, Cambridge.

[15] ILO,(2017). World Employment social Outlook 2017 "ILO, Geneva, 2014 Access: http://www.lo.org

[16] ILO,(2017). Global Employment for women Trends,ILO, Geneva, 2017 Access: http://www.lo.org.p. 14-30

[17] ILO,(2011) Decent Work For Young People: Key Messages,

[18] http://www.llo.org/public/english/employment/skills/youth/decent.htm, 
[19] ILO,YEN.(2016).The Youth Employment Network, http://www.lo.org/Public/English/employmenth/yen/about/index.htm

[20] TIRE O. ( 2017) Toplumsal Cinsiyet Açısından Türkiye deki Kadınların Yoksulluğu http://dergipark.gov.tr/download/article-file/293769

[21] KARAGÖL, E. T.,(2016)" G-20 de İşgücü ve İstihdam", İ̧̧KUR, Journal of İstihdam Issue No:18,Ankara, January-2016, p.17-18

[22] KARADENiZ O. Türkiye de Atipik Çalışan Kadınlar ve Yaygın Ssyal Güvencesizlik,Çalışma ve Toplum,2011/2, Ankara, file:////karadeniz.pdf

[23] KAYALI, G. S., (2015) Youth Unemployment, Türk Metal Publications, Ankara, p.150, 56

[24] KAYHAN, N. (2016). A study on the Problem of Globalızed Young Unemployment in Turkey Through Statıstıcal Data 2.nd Sarajevo International Conference by FBA

[25] KAYHAN, N. (2010) Küreselleşme Sürecinde Sosyal Haklarda Geri Çekilme Bağlamında, Türkiye de Yıllık İzin Hakkı ve Bazı Uygulama Sorunları ,Tes İş Publications, Ankara, 2010, p.20-25

[26] KAYHAN, N.(2009) 21. Yüzyılda Japonya'da İnsan Kaynakları Yönetimi ve Endüstriyel Iliş̧iler Sistemindeki Değişim, Karizma Ltd.. Ankara, 2009.

[27] KAYHAN, N.(2007) "AB Sürecinde Türkiye nin Meslek Eğitiminde Verimlilik Arayışları ve İstihdam" Bilgi Çağında Türk Kamu Yönetiminin Yeniden Yapılandırılması-11,Ed.A. Nohutçu, A. Balcı Beta, İstanbul, p.372-395

[28] KAYHAN, N.(2005) "Türkiye'de kadın işgücü, İstanbul İmalat sektöründeki çalışma şartları ve kayıt dışı istihdam", http://www.tuhis.org.tr/upload/dergi/1348753954.pdf

[29] KALKINMA BAKANLIĞI, (2014).10.Kalkınma Planı, 2014-2018 İstihdam http://www.cka.org.tr/dosyalar/Ozel\%20lhtisas\%20Komisyonu\%20Raporlar

[30] KILIÇ D. ÖZTÜRK S. (2014) Türkiye deki Kadınların işgücüne katılımı önündeki engeller ve çözüm yolları,Amme İdaresi Dergisi ,Cit 47,Sayı.1.TODAI, Ankara

[31] KORKMAZ, M. (2015). "Kadının Çalışma Hayatındaki Yeri ve Önemi, Ed. Korkmaz M. Vd. Dünya da ve Türkiye de Kadın ve Şiddet, Nobel Publishing, Ankara,2015 p.231-266

[32] KOSGEB,(2016). "Girişimcilik Destek Programı", http://www.kosgeb.gov.tr/Pages/UI/Destekler.aspx?ref=8,

[33] OECD (2016). Youth not in education or Employment,201, (NEET) (Indicator)

[34] ttp://www.oecd-ilibrary.org/employment/oecd-labour-force-statistics_

[35] OECD.Employment-Outlook-Turkey-2017.pdf,

[36] OECD.org.tr.- Labour Force Statistics (2017)

[37] ÖNDER N. Türkiye de Kadın İşgücünün Görünümü, file:///ÇSGB Çalışma Dünyası Dergisi pdf

[38] PAZARLIOĞLU M. V. - TURGUTLU T. (2007). "Gelir, İşsizlik ve Suç: Türkiye Üzerine Bir İnceleme",Finans Politik \& Ekonomik Yorumlar Volume: 44 Issue No:513. http://www.ekonomikyorumlar.com.tr/dergiler/makaleler/513/Sayi_513_Makale_04.pdf

[39] PETROL-İs,(2017). "ICFTU : Kadın Emeği ve Güvencesizlik ", Petrol İş Sendikası Notlar Journal, Issue No:54, January: 2017 https://www.petrol-is.org.tr/kadindergisi/sayi54/kadinistihdami.htm

[40] STATISTA (2015). "Youth Unemployment Still Unrelenting" in Europe https://www.statista.com/chart/3644/youth-unemployment-stillunrelenting-in-europe/

[41] STIGLITZ, Joseph E.,(2002). Küreselleşme Büyük Hayal Kırıkı̆̆ı, 3rd Edition. Plan B Publications, İstanbul

[42] TiSK, Genel $\quad$ Kurul $\quad$ Çalışma $\quad$ Raporu,(2016)

[43] TiRE O. ( 2017) Toplumsal Cinsiyet Açısından Türkiye deki Kadınların Yoksulluğu http://dergipark.gov.tr/download/article-file/293769

[44] TOKER A.(1999).Türkiye de Kadın İşgücü, TiSK Türkiye de Kadın İşücü Seminerleri 1-2 (1999).Publication No:192, Ankara,1999

[45] Türkiye de Kadın Emeği ve İstihdama Yönelik Politikaları (2013).KĖंG.Org.tr

[46] Türkiye de ve Dünyada Kadın Emeği ve İstihdamına Ilişkin Rapor(2010), Sosyal İs Org.tr

[47] TÜIK, (2017). Kadın İstihdam Verileri, 2017 -http://www.tuik.gov.tr/PreHaberBultenleri.do?id=15844

[48] TÜIK İstatistikler ile Kadın; TÜIK-2017. file:///C:/Istatistiklerle_Kadın_07.03.2017.pdf

[49] TÜIK, (2016). HHIA October-2015,http://www.tuik.gov.tr/PreHaberBultenleri.do?id=15844

[50] TÜRKONFED (2017) İş Dünyası Kadın 2017 raporu, 1st Phase Working Results, http://www.turkonfed.org/tr/icerikler/arastirmaraporlari/

[51] UNDP, Human Development Report 2009, "Overcoming Barriers: Human Mobility and Development", http://hdr.undp.org/en/media/HDR_2009_EN_Complete.pdf,

[52] WEF(2016). World Economic Forum 2016 Report, http://www.dw.com/tr/türkiyenin-cinsiyet--karnesi.pdf

[53] YENITÜRK N.,Başlevent C., (2007). Türkiye de Genç İşsizliği, Research Report of Youth Studies Unit, Bahçeşehir University ,İstanbul

[54] YILDIZ Ö. (2013) İşverenin Bakış Açısından Türkiye de Kadın İstihdamı, A Field Study, 9 Eylül. University. yildiz_ozkan.pdf

[55] http://www.hurriyetdailynews.com(2013)./women-employment-in-turkey-shows-high-rise-but-low-quality.

[56] http://kadininstatusu.aile.gov.tr/ulusal-eylem-planlari/toplumsal-cinsiyet-esitligi-ulusal-eylem-plani

[57] file:///C:/Users/ kale_04.pd 